IZA DP No. 9892

Spatial Income Inequality in India, 1993-2011:

A District Level Decomposition

Mehtabul Azam

Vipul Bhatt

April 2016 


\title{
Spatial Income Inequality in India, 1993-2011: A District Level Decomposition
}

\author{
Mehtabul Azam \\ Oklahoma State University \\ and IZA \\ Vipul Bhatt \\ James Madison University
}
Discussion Paper No. 9892
April 2016

\author{
IZA \\ P.O. Box 7240 \\ 53072 Bonn \\ Germany \\ Phone: +49-228-3894-0 \\ Fax: +49-228-3894-180 \\ E-mail: iza@iza.org
}

\begin{abstract}
Any opinions expressed here are those of the author(s) and not those of IZA. Research published in this series may include views on policy, but the institute itself takes no institutional policy positions. The IZA research network is committed to the IZA Guiding Principles of Research Integrity.

The Institute for the Study of Labor (IZA) in Bonn is a local and virtual international research center and a place of communication between science, politics and business. IZA is an independent nonprofit organization supported by Deutsche Post Foundation. The center is associated with the University of Bonn and offers a stimulating research environment through its international network, workshops and conferences, data service, project support, research visits and doctoral program. IZA engages in (i) original and internationally competitive research in all fields of labor economics, (ii) development of policy concepts, and (iii) dissemination of research results and concepts to the interested public.
\end{abstract}

IZA Discussion Papers often represent preliminary work and are circulated to encourage discussion. Citation of such a paper should account for its provisional character. A revised version may be available directly from the author. 
IZA Discussion Paper No. 9892

April 2016

\section{ABSTRACT \\ Spatial Income Inequality in India, 1993-2011: A District Level Decomposition}

Using nationally representative household survey data, and district and state as two levels of aggregation, we examine role of individual and geographical factors in determining the level and the change in income inequality in India. We find that between-state income differences account for the majority of between-district income inequality in rural India in 2011. However, in urban India within-state income differences explain most of the between- district inequality in 2011. We also find that the between-district component accounts for one-third of the increase in total income inequality in rural India between 1993 and 2011. We find significantly smaller level of inequality but similar trends using the consumption expenditure data.

JEL Classification: $\quad 130,132$

Keywords: income inequality, regional inequality, India

Corresponding author:

Mehtabul Azam

326 Business Building

Spears School of Business

Oklahoma State University

Stillwater, OK 74078

USA

E-mail: mazam@okstate.edu 


\section{Introduction}

In recent decades there has been a marked increase in income inequality in developed as well as developing countries. Gini coefficient, a commonly used measure of income inequality, for OECD countries has increased from 0.29 in 1980 s to 0.31 in late 2000s, with 17 out of 22 member countries witnessing an increase during this period (OECD, 2011). Many of the large emerging economies have also experienced steep increases in income inequality since 1990s (OECD, 2011). In terms of levels, emerging economies tend to have greater degree of inequality than developed countries. For instance, in 2011 the Gini coefficient averaged 0.31 in OECD countries with the highest value of 0.51 for Chile. In the U.S. the Gini coefficient stood at 0.39 in 2012 indicating a higher degree of income inequality in the U.S. when compared to the OECD. ${ }^{1}$ Among large emerging economies, in 2011 the Gini coefficient stood at $0.634,0.542,0.531,0.481,0.474$, and 0.41 for South Africa, Columbia, Brazil, Mexico, China, and Russia, respectively. ${ }^{2}$ These high levels of income inequality and the widespread increase in such inequality in recent decades has spurred active public policy discourse over the impact of rising inequality on economic development.

After initiating the market oriented reforms in 1991 India has experienced rapid economic growth, experiencing an annual average rate of real GDP growth of 6.6 percent between 1992-2011. India has also made significant progress in terms of reducing the incidence of extreme poverty with the poverty head count ratio (HCR) at the international poverty line

\footnotetext{
${ }^{1}$ Source: http://www.oecd.org/social/income-distribution-database.htm

${ }^{2}$ For Mexico and China the number is for the year $2012 . \quad$ Source: http://data.worldbank.org/indicator/SI.POV.GINI and http://www.economist.com/news/china/21570749gini-out-bottle
} 
of $\$ 1.90 /$ day (2011 PPP) falling from 46.1 in 1993 to 21.3 in $2010 .^{3}$ However, there are also increasing concerns about increasing inequality. In early 1990s, India was home to two resident billionaires with a share of one percent in GDP. In 2012 the number of resident billionaires stood at 46 and their share in GDP rose to 10 percent. ${ }^{4}$ As such, India is an outlier in the ratio of billionaire wealth to GDP among economies at a similar development level (Rama et al., 2014).

An important dimension of the India's economic growth experience in the last two decades has been the rather uneven distribution of this growth across Indian states. For instance, Chaudhuri and Ravallion (2006) used data for the sixteen major states of India and documented substantial cross-state variation in growth of state domestic product between 19782004. The state of Bihar recorded the lowest growth rate of 2.2 percent during this period, whereas the state of Karnataka was the top performer with an average growth of 7.2 percent. Given such large disparities in the gross domestic product growth rates between states, it is imperative to investigate how much of income inequality among individuals in India can be attributed to their place of residence. Understanding the spatial dimension of inequality, both in terms of extent and evolution over time, is of importance for policymakers as it offers critical insight into the process of economic development.

In comparison to other countries in the world India is generally considered to be a country with relatively moderate degree of inequality. The inequality estimates for India reported in the official government documents (as well as in official reports from organizations such as UN, OECD, and World Bank) are based on consumption expenditure collected by the

\footnotetext{
${ }^{3}$ Authors calculation using data from: http://povertydata.worldbank.org/poverty/country/IND.

${ }^{4}$ Source: Surging tides of inequality, The Hindu, July 11, 2015.
} 
National Sample Survey (NSS). Using this data the Gini coefficient for India has increased from 0.325 in 1993 to 0.375 in $2011-12 .{ }^{5}$ However, inequality estimates for most of the OECD and emerging economies are based on income data, and there is a general consensus that inequality measures based on income tend to be larger than those based on consumption expenditure. Hence, in order to appropriately compare India with other countries, it is imperative to estimate the extent of inequality based on income data. The India Human Development Survey (IHDS) collected large scale household surveys in 2004-05 and 2011-12 with data on income. Based on income data in IHDS, the Gini for India is 0.536 and 0.543 for 2004-05 and 2011-12, respectively. ${ }^{6}$ Hence, income inequality in India is comparable to other major emerging economies such as Brazil and greater than the level observed in China, Russia, and Mexico.

In this paper, we examine the income inequality in rural and urban India with the objective of understanding the role played by spatial factors in driving such inequality. Using individual-level income data and additively decomposable class of Generalized Entropy (GE) indices, namely, Theil and the mean log deviation (MLD), we estimate the fraction of total rural income inequality that is due to differences in mean income between districts (between-district component) and fraction of inequality that is due to household-level differences within the same district (within-district component) in 2011. We also track changes in these components over time and examine the importance of the two components in terms of their contribution to the change in total rural income inequality between 1993 and $2011 .^{7}$

\footnotetext{
${ }^{5}$ Authors calculations from NSS 50th and NSS 68th round of consumer expenditure surveys.

${ }^{6}$ In contrast, the Gini based on consumption data in IHDS surveys are only 0.395 and 0.384 for 2011-12 and 2004-04, respectively.

${ }^{7}$ Due to non-availability of income data for urban India in 1993 we cannot estimate the change in urban income inequality over time.
} 
Furthermore, given that most of the literature on inequality in India is based on consumption expenditure data, we also use NSS data to provide comparable estimates of consumption expenditure inequality for both urban and rural India. Finally, we use a regression based decomposition analysis to understand the role played by household characteristics in explaining the income inequality dynamics in rural India during 1993-2011.

We contribute to the existing literature in the following ways. First, in contrast to the existing literature on India that uses consumption expenditure, our inequality estimates are based on income, which is comparable to the estimates for other major emerging economies as well as OECD countries. Second, using the district as a geographical unit, we significantly improve the existing estimates of spatial inequality in India that are based on either ruralurban comparisons or across state comparisons. Third, we also provide an estimate of how the spatial component of income inequality has evolved over time in the face of rapid economic growth experienced by India between 1993 and 2011.

There are several findings of interest. First, we find that the extent of income inequality in India is comparable to the levels observed in many high income inequality countries such as China, Mexico, Chile, Brazil, and Columbia. For instance, in 2011 the Gini coefficient for rural India was 0.508 and that for urban India was 0.490. Second, in 2011 about onefifth of the total income inequality in both urban and rural India can be attributed to between-district mean differences in income. In rural India, most of the between-district inequality is accounted for by mean income differences across states. However, in urban India, it is the within-state district differences that contribute significantly to the betweendistrict inequality. Third, we find that the income inequality in rural India is higher than the 
income inequality in urban India in 2011 based on all three measures of inequality (Theil, MLD, and Gini) considered in this paper. This is in contrast to the consumption inequality which is higher in urban India compared to rural India in 2011.

Fourth, the income inequality in rural India increased between 1993 and 2011 based on all three measures of inequality, and the increase in between-district inequality accounted for one-third of the total increase in rural income inequality between 1993 and 2011. Moreover, the majority of the increase in between-district inequality in rural India is driven by increase in mean differences in income across states. Fifth, we find similar trends over time in consumption data from NSS, however, the inequality estimates based on consumption data are much lower when compared to those obtained using income data. Finally, our regression based decomposition reveals interesting patterns. In terms of contribution to the increase in rural income inequality between 1993 and 2011, district fixed effects that capture the spatial component emerge as a significant contributor confirming the increasingly important role played by spatial factors in driving income inequality in rural India. However, a substantial part of the total inequality remained unexplained by the observed household level characteristics.

The findings of our paper have important implications for development policy in India. The increasing role of state-level differences in rural income inequality suggests that policies that encourage more even economic growth, for example through allocation of infrastructural investments across states, need to be followed. Kanbur (2006) argues that often regional divisions align with ethnolinguistic and/or social identity dimensions, and ignoring 
such inequality between regions may be harmful for political stability and regional harmony. ${ }^{8}$ Although the share of within-district inequality remains large, our regression based decomposition suggests that the majority of the income inequality remains unexplained. As a result it is difficult to draw conclusions that affect individual heterogeneity within state/district.

The paper is organized as follows. Section 2 provides a brief review of the existing literature on inequality in India. Section 3 details the empirical methodology used in the paper. Section 4 describes the data. Section 5 presents the results, and Section 6 concludes.

\section{Related Literature}

The issue of inequality in India has drawn a considerable academic interest. Almost all the existing literature on inequality in India utilizes the NSS consumption expenditure data. The focus has been explaining change in consumption inequality through household characteristics (e.g., Cain et al., 2010), and explaining differences in caste consumption inequality (e.g., Kijima, 2006b; Motiram and Vakulabharanam, 2012). Another set of studies have focused on changes in wage structure/inequality using wage information collected in NSS employment round surveys. Since, majority of salaried jobs are concentrated in urban areas, majority of these studies limit themselves to urban India (e.g., Azam, 2012, Kijima, 2006a).

The spatial dimension of inequality even with the consumption expenditure has largely

\footnotetext{
${ }^{8}$ As is commonplace in this literature, we find that in each time period the regional decomposition of total income inequality in rural India yield a smaller between-component when compared to the within-component. As a result one may argue that targeting the within-component will bring about a larger reduction in total inequality. Kanbur (2006) underscores the problem associated with such an approach. For instance, it is possible that the between-group component, although smaller in magnitude, has a large role to play in the change in the total inequality over time. We find that one-third of the increase in income inequality in rural India between 1993 and 2011 is due to between-district component.
} 
remained under researched. In this relatively sparse literature, the focus has mostly been either on urban-rural differences (e.g., Chamarbagwala, 2010) or documenting state-level inequality based on consumption expenditure (e.g., Dev and Ravi, 2007). ${ }^{9}$ There are only few studies that addressed the regional inequality in India using individual level data. Mishra and Parikh (1992) use NSS consumer expenditure data for 1977-78 and 1983, and divide the total inequality into within and between components based on states as geographic units. Motiram and Vakulabharanam (2012) use the NSS data and decompose inequality in consumption expenditure into within-state and between-state inequality. They find that the share contributed by the between component increased between 1993-94 and 2004-05 and this trend continued into the period 2004-05 to 2009-10.

\section{Empirical Framework}

\subsection{Regional Decomposition of Income Inequality}

Our analysis of spatial inequality is based on individual income data. Following Gustafsson and Shi (2002), the individual incomes can be aggregated hierarchically to districts and the district-level income can be clustered to states. To illustrate this approach we first express total inequality in India as the weighted sum of inequality within each district and betweendistricts:

$$
\text { Total inequality in India }=\text { Within-district inequality }+ \text { Between-district inequality }
$$

\footnotetext{
${ }^{9} \mathrm{~A}$ number of papers study inter-regional convergence using aggregated per capita State Domestic Product (SDP). Their focus is often to test for unconditional and conditional convergence in per capita SDP across different states and union territories of India (Das and Barua, 1996; Nayyar, 2008).
} 
This enables us to capture the inequality at the lowest administrative level possible from the survey data. As each district belongs to a state, we next aggregate district income to arrive at the average income for each state. Therefore between-district inequality can be expressed as sum of between-state and within-state inequality:

$$
\begin{gathered}
\text { Between-district inequality } \\
=\underset{(\text { district-level })}{\text { Within-state inequality }}+\underset{(\text { district-level })}{\text { Between-state inequaly }}
\end{gathered}
$$

Hence, by implementing the above decomposition we can estimate the relative importance of spatial factors (between-components) at different levels of aggregation to income inequality in India. We use two widely used additively decomposable indices, namely, Theil coefficient and the mean log deviation (MLD), to estimate income inequality. Both belong to the family of generalized entropy (GE) inequality measures and satisfy the criteria that constitutes a good measure of income inequality. ${ }^{10}$ The Theil Index is defined as:

$$
T=\frac{1}{n} \sum_{i=1}^{n}\left(\frac{y_{i}}{\bar{y}}\right) \log \left(\frac{y_{i}}{\bar{y}}\right)
$$

where $y_{i}$ is the per capita income of the $i$ th individual, $\bar{y}$ is the mean income per person, and $n$ is the number of individuals.

The second index of generalized entropy family is the Mean Logarithmic Deviation (MLD)

\footnotetext{
${ }^{10}$ Haughton and Khandker (2009) details six criterion for a good measure of inequality: 1) Mean independence: if all incomes were doubled, the measure would not change. 2) Population size independence: if the population were to change, the measure of inequality should not change. 3) Symmetry: if any two people swap incomes, there should be no change in the measure of inequality. 4) Pigou-Dalton Transfer sensitivity: if the income is transferred from rich to poor, the inequality should decrease. 5) Decomposability: inequality may be broken down by population groups or income sources or in other dimensions. 6) Statistical testability: one should be able to test for the significance of changes in the index over time. They also note that statistical testability is less of a problem than it used to be because confidence intervals can typically be generated using bootstrap techniques.
} 
defined as:

$$
L=\frac{1}{n} \sum_{i=1}^{n} \log \left(\frac{\bar{y}}{y_{i}}\right)
$$

If the sample is divided into $k$ districts, the Theil index can be decomposed as:

$$
T=\sum_{j=1}^{k}\left(\frac{Y_{j}}{Y}\right) T_{j}+\sum_{j=1}^{k}\left(\frac{Y_{j}}{Y}\right) \log \left(\frac{Y_{j} / Y}{n_{j} / n}\right)
$$

where $n_{j}$ is the number of individuals in the $j$ th district, $T_{j}$ is inequality within the $j$ th district, $Y$ is the total income of all $n$ individuals in the sample, and $Y_{j}$ is the total income in district $k$. The first term of the above equation represents within-group inequality while the second term measures the between-group inequality. The between-group term represents the level of inequality that would be observed if the income of each person is replaced by the mean income of his or her respective district. It therefore provides the most immediate answer to the counterfactual question "how much inequality would be observed if there was no inequality within district?" (Shorrocks and Wan, 2005).

The MLD can be decomposed as:

$$
L=\sum_{j=1}^{k} \frac{n_{j}}{n} L_{j}+\sum_{j=1}^{k} \frac{n_{j}}{n} \log \left(\frac{\bar{y}}{\bar{y}_{j}}\right)
$$

where $\bar{y}_{j}$ is the mean income in district $j, \bar{y}$ is the mean income of entire sample (country), and $L_{j}$ is inequality within the $j$ th district. The first term of the above equation represents within-group inequality while the second term measures the between-group inequality. ${ }^{11}$

\footnotetext{
${ }^{11}$ We use publicly available Stata program "ineqdeco" written by Stephen P. Jenkins for our decomposition (Jenkins, 1999).
} 


\subsection{Regression-Based Decomposition of Income Inequality}

We also use a regression-based decomposition that allows us to estimate the contribution of various household characteristics in addition to the spatial factors to total inequality in rural India. Further, we can estimate the extent to which these characteristics contributed to the change in inequality over time. Cowell and Fiorio (2011) show that there is a link between the between-component from the regional decomposition outlined in Section 3.1 and the sum of the estimated inequality shares of the indicator variables for geographical units (districts) in the regression framework. The two different measures of the between-component allow us to test the robustness of our findings for spatial inequality in India. In addition, we can also examine the role played by observed household characteristics in driving the income inequality over time. Hence, the regression-based decomposition offers additional insights about inequality dynamics and complements our regional decomposition analysis.

Following Fields (2003), we first estimate the following log-linear income generating process:

$$
y_{j}=\beta_{0}+\sum_{k=1}^{K} \beta_{k} X_{k j}+\epsilon_{j}
$$

where $y_{j}$ denotes the natural logarithm of per capita income of household $j$ and $X_{k j}$ refers to characteristic $k$ specific to household $j$. These include the household demographic characteristics, household head characteristics such as age, education, occupation, household main income source, and indicator variables for districts. Table A3 in the appendix provides a complete list of the variables included in the regression model. Fields (2003) shows that one can treat each $\beta_{k} X_{k}$ and the residual like an income source in the Shorrock's (1982) 
sense, and define the relative characteristic inequality weight as:

$$
s_{k}(y)=\frac{\operatorname{Cov}\left(\hat{\beta}_{k} X_{k}, y\right)}{\hat{\sigma}^{2}(y)}
$$

Using these shares it is straightforward to derive the contribution of household characteristic $k$ to the change in any measure of income inequality $I(Y)$ between 1993 and 2011 as follows: ${ }^{12}$

$$
\Delta I_{k}=\frac{s_{k}^{2011} \times I^{2011}-s_{k}^{1993} \times I^{1993}}{I^{2011}-I^{1993}}
$$

\section{Data}

We use two large scale household surveys collected in 1993-94 and 2011-12 (henceforth, 1993 and 2011, respectively). The 1993 survey, known as Human Development Profile of India (HDPI), was conducted by National Council of Applied Economic Research (NCAER), and the 2011 survey known as India Human Development Survey-2 (IHDS-2) was collected jointly by NCAER and the University of Maryland. ${ }^{13}$ The HDPI is a random sample of 33,230 households from rural India, located in 16 major states, 195 districts and 1,765 villages. The IHDS-2 was administered across all states both in urban and rural areas, and surveyed 27,579 households in rural India and 14,573 households in urban India. As one of the objective of

\footnotetext{
${ }^{12}$ Fields (2003) argues that the inequality index $I(Y)$ should be is continuous, symmetric and $I(\mu, \mu, \ldots \ldots, \mu)=0$, where $\mu$ is the mean income. Virtually all inequality indices satisfy these conditions, including the Gini coefficient, the Atkinson index, the generalized entropy family, the coefficient of variation, and various centile measures (Fields, 2003).

${ }^{13}$ IHDS data is publicly available from Inter-university Consortium for Political and Social Research (ICPSR). HDPI data can be accessed from NCAER on request. See ihds.info, Shariff (1999), and Desai and Vanneman (2015) for details.
} 
this paper is to compare the changes in income inequality, we restrict our rural sample to only those 16 major states which were part of 1993 sample to maintain comparability between 1993 and 2011. ${ }^{14}$ We further restrict our 2011 sample to only those districts that are covered in the 1993 data. $^{15}$ Thus, our rural sample in 2011 contain not only the same number of districts but also the same districts as our rural sample in $1993 .{ }^{16}$ Our 2011 working sample include 24,855 rural households and 14,456 urban households. ${ }^{17}$

The HDPI and IHDS collect detailed information on household income from various sources. ${ }^{18}$ The definition of income remains similar across the two data sets. Although the IHDS-2 collected consumption expenditure in addition to income, the HDPI only collected expenditure on food, education, and health, and not overall consumption expenditure. Hence, in order to contrast the trends observed in income data with those in consumption expenditure data, we use the widely used NSS consumption rounds. NSS administer large scale household consumption rounds every five-year that collects detailed information of household expenditure. The available NSS consumption rounds that overlaps with the same time horizon as HDPI/IHDS were collected in 1993-94 and 2011-12. Unfortunately, the

\footnotetext{
${ }^{14}$ According to Census 2011, these major 16 states accounts for $97.5 \%$ of the total rural population. In 2001, the state of Jharkhand, Chattisgarh, and Uttarakhand was carved out from Bihar, Madhya Pradesh, and Uttar Pradesh, respectively. In 2011 data these split states are recoded as parental states.

${ }^{15}$ Shorrocks and Wan (2005) suggest a non-decreasing relationship between the number of groups and the magnitude of the between-group inequality. They argue that an increase in the number of groups will increase the opportunities for differentiating between the group mean values used in the calculation of between-group, thereby causing the value of between-group to rise.

${ }^{16}$ Some districts were split in two or more districts between 1993 and 2011. In that case we recoded the 2011 split districts to parental districts as identified in the 1993 data. In the 1990s, there were 466 districts in India (according to Census 1991), which implies an average population of 2.6 million per district in 2011 (Census 2011).

${ }^{17} \mathrm{We}$ also dropped households that has negative or zero income in 2011.

${ }^{18}$ The different sources of household income include: a) Farm income: value of production for sale and own consumption, and income generated from allied agricultural activities like cattle tendering; b) Salary Income: salaries from regular employment; c) Agricultural and non-agricultural wages: wages from casual employment in agriculture and non-agriculture activities; d) Income from self-employment activities; e) Income from rent, pension, remittances etc.
} 
1993-94 data does not provide the district identifier which is our lowest geographical area of analysis. As a result we use the NSS consumption round data for 1999-00 and 2011-12. We ensure that both 1999-00 and 2011-12 NSS data contain the same set of districts. Since, the NSS were administered both in urban and rural area, we are able to comment on changes in inequality in both urban and rural India based on consumption expenditure.

Household income (consumption expenditure) is normalized by household size to get per capita levels which is used throughout our empirical analysis. We also account for the survey weights provided in the data and household size. ${ }^{19}$ To adjust for price changes over time we use state-level poverty line estimates. Table 1 provides the information about the number of households/individuals in each state in our rural sample. Column (3) and (4) of Table 1 provide the maximum and minimum number of individual observations in district within a state.

\section{$5 \quad$ Empirical Findings}

\subsection{Inequality in rural India}

According to Census 2011, about $69 \%$ of the Indian population reside in rural areas. Therefore, changes in income inequality in rural India affects a much larger population than changes in income inequality in urban India. Table 2 presents the decomposition of total rural inequality into within and between components at different levels of aggregation for 1993 and 2011. Column (7) and (8) of the Table 2 presents the change in contribution of

\footnotetext{
${ }^{19}$ Household weight is multiplied by household size to obtain distribution of persons.
} 
each component between 1993 and 2011. At the all India level, we find that rural inequality has increased substantially between 1993 and 2011. The MLD index increased from 0.356 in 1993 to 0.474 in 2011, an increase of 33 percent; the Theil index increased from 0.394 in 1993 to 0.549 in 2011, an increase of 39 percent. Similarly, the Gini for income increased from 0.450 to 0.508 , an increase of around 13 percent. $^{20}$

The decomposition of the total rural income inequality into within-district and betweendistrict components indicates that most of the rural inequality can be attributed to the within-district component in both years. However, the share of this component in total income inequality declined between 1993 and 2011. In contrast the share of the betweendistrict component increased from 14 (13) percent based on MLD (Theil) to 19 (18) percent during this period. These results imply that if we equalize the average per capita income across districts then almost one-fifth of the total rural income inequality will disappear in 2011.

The decomposition of the between-district income inequality into within-state (district level) and between-state (district level) components highlight the rising importance of spatial factors in rural income inequality. From Table 2, we observe that within-state (district level) contributes 6-7 percent of the total rural inequality and its share does not change over time. In contrast, the share of between-state (district level) increased to 12 percent in 2011 from 7-8 percent in 1993. Hence, if we equalize the average per capita income across different states in our sample then more than one-tenth of the total rural income inequality will

\footnotetext{
${ }^{20}$ We also computed consumption inequality in rural India using the NSS consumption expenditure data for 1993-94 and 2011-12. The Gini coefficient in consumption expenditure for rural India increased from 0.286 in 1993 to 0.311 in 2011-12: an increase of 9 percent. Hence, inequality increased in rural India between 1993 and 2011 based on both income and consumption measures.
} 
disappear in 2011. It is also worth noticing that the increase in inequality between 1993 and 2011 is driven by an increase in both within-district and between-district components. For instance, in terms of MLD, 34 percent of the increase in rural income equality can be attributed to the increased mean differences in average per capita income across districts, i.e., the between-component. Importantly, about four-fifth of the increase in between-district inequality between 1993 and 2001 is contributed by an increase in between-state inequality. Moreover, the between-state income differences account for about one-quarter of the total increase in rural income inequality between 1993 and 2011. Hence, our results indicate that the inter-state inequality played an important role in driving the total rural income inequality implying a significant divergence in income per capita across states in India. This is also evident from the fact that the standard deviation of mean per capita income across states more than doubled during our sample period.

We also computed an equivalent of Table 2 using NSS consumer expenditure data for 1999-00 and 2011-12. ${ }^{21}$ Table A1 in the appendix presents those results. There are two important findings from this Table. First, all three measures of inequality-Theil, MLD, and Gini- suggest a much lower level of inequality in rural India when compared to income inequality. Second, both within and between component contributed to increase in consumption inequality between 1999 and 2011. The between-state inequality contributed about 29 (16) percent of the total increase in inequality based on MLD (Theil) index. These results indicate that in terms of inequality trend, both consumption and income data exhibit similar

\footnotetext{
${ }^{21}$ As discussed in the data section, we are unable to decompose the inequality at district level using the 1993 NSS consumer expenditure data as the 1993 data does not identify districts. The closest NSS consumer expenditure data available is 1999 .
} 
patterns during our sample period.

In Table $3 \mathrm{a}$ and $3 \mathrm{~b}$ we present state level per capita income at 2011 prices, measures of income inequality, and the decomposition of the state level income inequality into betweendistrict and within-district components. There are several findings of interest. First, with the exception of Madhya Pradesh, every state in our sample has witnessed an increase in rural average real per capita income. Second, between 1993 and 2011, eleven out of sixteen states have witnessed an increase in income inequality in terms of all three measures of inequality. ${ }^{22}$ Hence, the rising rural inequality in the presence of rising incomes during our sample period is a pan-India phenomenon and not limited to a small number of states. Third, from the decomposition results we find that the within-district inequality accounts for almost all of the state-level inequality, averaging 93 (94) percent for MLD (Theil) in both years.

To summarize the discussion in this section, our results indicate that rural income inequality has been on the rise in India since 1993 in the presence of rising rural incomes. Although in both time periods a large share of the total income inequality was accounted for by the within-district component, the between-component has become increasingly important in explaining the increase in inequality during this period. This suggest that spatial factors are becoming an important driver of inequality over time in rural India.

\footnotetext{
${ }^{22}$ Note that of the five states that witnessed a decline in income inequality, only for Karnataka and Tamil Nadu, all three measures of inequality indicated a decline.
} 


\subsection{Inequality in Urban India}

In Table 4 we present the level of urban income inequality and its decomposition at different levels of regional aggregation for $2011 .{ }^{23}$ In terms of all three measures of inequality urban income inequality in India is lower than the rural income inequality as reported in Table 2. In contrast, the consumption inequality from NSS consumption expenditure data suggest a higher consumption inequality in urban India in both 1999 and 2011 (see appendix Table A1 and A2). ${ }^{24}$ Further, the decomposition of total urban income inequality reveals that although a large part of total income income inequality in urban areas can be attributed to within-district inequality, between-district inequality is also important. For instance, if the average income across districts are made equal, then the total income inequality in urban India will decrease by one-fifth. However, the decomposition of between-district inequality in urban India yields different results compared to rural India. The between-state (districtlevel) component only accounts for 7 percent of the total income inequality observed in 2011 in urban India, whereas it accounted 12 percent for the total rural income inequality.

For comparison, appendix Table A2 provides similar estimates based on NSS consumption expenditure for urban India for 1999 and 2011. Based on all three measures of income inequality the consumption inequality in urban India has also increased between 1999 and 2011. Moreover, both within and between-district component of consumption inequality increased over time. Importantly, about $41-45 \%$ of the increase in consumption inequality

\footnotetext{
${ }^{23}$ We cannot compare the inequality in urban India in 2011 to 1993 as the 1993 HDPI survey was only administered in rural India. Although the earlier wave of IHDS collected in 2004-05 also has an urban sample, we do not use that as the time span is too short to capture the role of spatial factors.

${ }^{24}$ As consumption expenditure data was also collected in the 2011 IHDS survey, we calculated the consumption inequality in both urban and rural India using IHDS consumption expenditure data. The Gini suggests a marginally higher consumption inequality in urban India, while the other two measures-Theil and MLD - suggest a marginally lower consumption inequality in urban India.
} 
observed during 1999-2011 is contributed by increased differences across districts. The nature of the increase in between-district consumption inequality is different in urban areas compared to rural areas. In contrast to rural areas, where most of the increase in betweendistrict consumption inequality is driven by increased differences in average consumption expenditure across states, in urban areas, the most of the increase in between-district consumption inequality is within-state. For example, in 2011, only 5 (6) percent of consumption inequality in urban India can be attributed to state-level mean consumption expenditure differences based on Theil (MLD). In contrast the state level differences accounted for 19 (15) percent of total consumption inequality in rural India. Moreover, the share of state-level differences in total consumption inequality remain same between 1999 and 2011 in urban India, while it increased in rural India.

These findings indicate that the nature of inequality and its evolution differ between rural and urban areas, with the spatial factors playing a much more important role in rural India during our sample period. In order to effectively address rising inequality in India the public policy discussions should take cognizance of this difference as it may necessitate using different policy tools in rural and urban India.

\subsection{Comparison with Emerging Economies}

In this section we compare India's income inequality experience with that of other emerging economies of the world. We begin by comparing our findings with the Chinese experience for the following two reasons. First, both countries have experienced rapid economic growth after successfully initiating market-oriented reforms, since 1980s in China and 1990s in India. 
Second, there is a large literature documenting rapidly rising income and consumption inequality in China which allows us to examine the differences in inequality dynamics for these two major economies in Asia. Gustafsson and Shi (2002) examined rural income inequality in China between 1988 and 1995 using household level income data. They find a significant spatial component to the rising income inequality in China during this period. They report that depending on the inequality measure used, mean income differences across counties account for around 52-64 percent of the increase in total rural inequality in China. Yu et al. (2007) used village data for China and studied the evolution on income inequality between 1997 and 2002. They find a large role for spatial factors with more than three-quarters of the rural income inequality in 1997 and 2002 in China accounted for by equalizing incomes across townships. In comparison to China, based on the results presented in this paper the within-component plays a larger role in accounting for income inequality in India. Nonetheless, the between-component has become an important contributor to the increase in overall rural income inequality. For instance, we find that mean income differences between districts can explain 30-34 percent of the increase in the total rural income inequality in India between 1993 and 2011.

Another interesting comparison with China is in terms of the level of inequality based on income and consumption data. Our results indicate that for India inequality based on income per capita is much higher than the level obtained using consumption per capita. This is in contrast to the findings of Cai et al. (2010) who find that in China consumption based inequality parallels income inequality closely and is the bigger of the two during the 1992-2003 period. They argue that this could be partly due to under-reporting of income in 
China and lack of consumption smoothing and insuring by Chinese households.

Yemtsov (2005) decomposed the regional inequality for Russia and found that in terms of the levels, most of the national inequality in Russia can be attributed to the within-region component (75 percent in 1994 and 68 percent in 2000). However, in terms of the trend, most of the increase in total inequality between 1994 and 2000 was due to the mean income differences between regions. Bayar (2016) investigates regional inequality across different regions for Turkey and finds that the within-region component is the dominant factor in the total income inequality in Turkey during 2006-2013. These patterns are similar to the findings reported for India in this paper.

\subsection{Regression Based Decomposition}

In this section, we discuss our findings from the regression-based decomposition of income inequality in rural India. Table A3 in the appendix presents the estimation results of equation (7) for 1993 and 2011. We find that the income generating model does a much better job of explaining variance of log income in 1993 when compared to 2011. In 1993, the variables included in the regression together explain $44.6 \%$ of the variance in log-income. In contrast, the included variables only explain 31.9\% of the variance in log-income in 2011.

Table 5 presents the factor inequality weights of variables for year 1993 and 2011, using the Gini coefficient as the measure of inequality. The residual - the part of inequality unexplained by the household characteristics in the regression-accounts for a large amount of total income inequality. This is common in regression based inequality decomposition (see, e.g. Brewer and Wren-Lewis, 2015; Cain et al., 2010; Cowell and Fiorio, 2011). For example, 
Cain et al. (2010) carried out similar regression based decomposition for India using the consumption expenditure data from NSS for year 1993 and 2004, and controlling for state fixed effects. They find much higher residual inequality weight in rural India, compared to ours. They find residual inequality weight of 79.66 percent in 1993 which declined marginally to 76.08 percent in 2008 . From Table 5 we observe that residual inequality weights are 57.69 percent and 68.15 percent in 1993 and 2011, respectively.

After the residual, the district fixed effects are the most important variable, with a factor inequality weight of $12 \%$ in 1993 and $14 \%$ in 2011. In column (4) and (5) of Table 5, we control for states fixed effects and find that the inequality weights are 5.5 and 8.7 percent in 1993 and 2011, respectively. Importantly, the inequality weight of geographical factors has increased between 1993 and 2011 which confirm our earlier finding of increasing role of spatial factors. Amount of land cultivated together with whether cultivate land or not has the third largest inequality weight in 1993. However, the weight of these variables declined considerably between 1993 and 2011.

Column (3) of Table 5 presents the contribution of different factors in change in Gini between 1993 and 2011 based on equation (7). Caste, education, household income source, and land contributed negatively in total change in Gini between the two time periods. However, these negative impacts are outweighed by a large positive contribution from residual inequality. Interestingly, the district fixed effects that capture the spatial component are the second largest contributor to the increase in total income inequality observed. Hence, our regression based decomposition results reiterate the increasing importance of spatial factors in the accounting for level and increase in inequality observed in rural India. 


\section{Conclusion}

In this paper, we study income inequality in India with a focus on the spatial dimension.

We examine how much of the total income inequality can be attributed to the spatial factors using district and states as two different levels of aggregation for our individual level income data, and whether the importance of spatial factors has increased over time.

We find that income inequality in rural India has increased between 1993 and 2011, and changes in average income across districts contributed about one-third to the observed increase in income inequality during this period. Importantly, these difference across districts are mostly due to the increasing differences in average rural income across states. In contrast to rural India, we find that most of the between-district differences in urban India are due to the within-state component. This highlights an important difference in the nature of income inequality between urban and rural India: the contribution of state average income differences is smaller in urban India when compared to rural India.

We also compare these findings to inequality based on per capita consumption expenditure data from NSS for 1999 and 2011. In both urban and rural areas, we find that the level of inequality is much lower when we use consumption data than the level of inequality based on income data. For rural India, our results for income inequality are confirmed and we find that income differences between different districts and states have contributed significantly to total inequality, and have become increasingly important over time. Similar to our findings for urban income inequality, we find that consumption inequality in urban areas is more of a within-district and within-state phenomenon, and hence is different in nature than rural income inequality. 


\section{References}

[1] Azam, M. (2012), "Changes in Wage Structure in Urban India, 1983-2004: A Quantile Regression Decomposition," 40 (6), 1135-1150.

[2] Barua, A. and Sawhney, A. (2015), "Development Policy Implications for Growth and Regional Inequality in a Small Open Economy: The Indian Case", Review of Development Economics, 19(2), 695-709.

[3] Bayar, A. A. (2016), "The Decomposition of Regional Income Inequalities of Turkey", Unpublished Manuscript.

[4] Brewer, M. and Wren-Lewis, L. (2015), "Accounting for Changes in Income Inequality: Decomposition Analyses for the UK, 1978-2008," Oxford Bulletin of Economics and Statistics. doi: 10.1111/obes.12113

[5] Cai, H., Chen, Y. and Zhou, L (2010), "Income and Consumption Inequality in Urban China: 1992-2003," Economic Development and Cultural Change, 58(3), 385-413.

[6] Cain, J.S., Hasan, R., Magsombol, R, Tandon, A. (2010), “Accounting for inequality in India: Evidence from household expenditures", World Development, 38 (3), 282-297.

[7] Chamarbagwala, R. (2010), "Economic liberalization and urban-rural inequality in India: a quantile regression analysis," Journal Empirical Economics, 39(2), 371-394.

[8] Chaudhuri, S. and Ravallion, M. (2006), "Partially awakened giants: Uneven growth in China and India," The World Bank Policy Research Papers. 
[9] Cowell, F. A. and Fiorio, C. V. (2011). "Inequality decompositions: a reconciliation", Journal of Economic Inequality, 9, 509-528.

[10] Das, S. K. and Barua, A. (1996), "Regional inequalities, economic growth and liberalisation: A study of the Indian economy", The Journal of Development Studies, 32(3), 364-390.

[11] Desai, S, Vanneman, R, and National Council of Applied Economic Research, New Delhi (2010). India Human Development Survey (IHDS), 2005. ICPSR22626-v8. Ann Arbor, MI: Inter-university Consortium for Political and Social Research [distributor], 2010-06-29. http://doi.org/10.3886/ICPSR22626.v8

[12] Desai, S, and Vanneman, R (2015). India Human Development Survey-II (IHDS-II), 2011-12. ICPSR36151-v2. Ann Arbor, MI: Inter-university Consortium for Political and Social Research [distributor], 2015-07-31. http://doi.org/10.3886/ICPSR36151.v2.

[13] Dev, M. S. and Ravi, C. (2007), "Poverty and Inequality: All-India and States, 1983200," Economic and Political Weekly, 42(6), 509-521.

[14] Fields, G. S. (2003). "Accounting for income inequality and its change: a new method, with application to the distribution of earnings in the United States", Research in Labor Economics, 22, 1-38.

[15] Gustafsson, B. and Shi, L. (2002), "Income inequality within and across counties in rural China 1988 and 1995", Journal of Development Economics, 69(1), 179-204. 
[16] Haughton, J. H. and Khandker, S. R. (2009), "Handbook on poverty and inequality," World Bank Publications.

[17] Jenkins, P. S. (1999), "POVDECO: Stata module to calculate poverty indices with decomposition by subgroup," Statistical Software Components S366004, Boston College Department of Economics, revised 28 Jan 2008.

[18] Kanbur, Ravi. (2006), "The policy significance of inequality decompositions." The Journal of Economic Inequality, 4(3), 367-374.

[19] Kijima, Y. (2006a), "Why did wage inequality increase? Evidence from urban India 1983-99", Journal of Development Economics, 81(1), 97-117.

[20] Kijima, Y. (2006b), "Caste and Tribe Inequality: Evidence from India, 1983-1999," Economic Development and Cultural Change, 54(2), 369-404.

[21] Mishra, P. and Parikh, A. (1992), "Household consumer expenditure inequalities in India: a decomposition analysis", Review of Income and Wealth, 38(2), 225-236.

[22] Motiram, S. and Vakulabharanam, V. (2012), "Indian Inequality: Patterns and Changes, 1993-2010," in Mahendra Dev (ed.) India Development Report, New Delhi: Oxford University Press.

[23] Nayyar. G. (2008), "Economic Growth and Regional Inequality in India," Economic and Political Weekly, 58-67.

[24] OECD (2011), "Divided We Stand: Why Inequality Keeps Rising, OECD Publishing. DOI:10.1787/9789264119536-en. 
[25] OECD (2015), "Overview of inequality trends, key findings and policy directions," in OECD, In It Together: Why Less Inequality Benefits All, OECD Publishing, Paris. DOI: http://dx.doi.org/10.1787/9789264235120-4-en.

[26] Rama, M., Béteille, T., Li, Y., Mitra, P.K., and Newman, J. L. (2014), "Addressing Inequality in South Asia," South Asia Development Forum;. World Bank Group, Washington, DC.

[27] Shariff, A. (1999), "India Human Development Report," New Delhi, Oxford University Press.

[28] Shorrocks, A. and Wan, G. (2005), "Spatial decomposition of inequality", Journal of Economic Geography, 59-81.

[29] Yemtsov, R. (2005), "Quo vadis? Inequality and poverty dynamics across Russian regions," in Kanbur, R. and Venables, A. J. ed "Spatial inequality and development," OUP.

[30] Yu, L., Luo, R., \& Zhang, L. (2007), "Decomposing income inequality and policy implications in rural China", China \& World Economy, 15(2), 44-58. 
Table 1: Sample Size, Rural India

\begin{tabular}{|c|c|c|c|c|c|c|c|c|}
\hline \multirow[b]{3}{*}{ State } & \multicolumn{4}{|c|}{1993} & \multicolumn{4}{|c|}{2011} \\
\hline & \multirow{2}{*}{$\frac{\text { Households }}{\mathrm{N}}$} & \multicolumn{3}{|c|}{ Individuals } & \multirow{2}{*}{$\frac{\text { Households }}{N}$} & \multicolumn{3}{|c|}{ Individuals } \\
\hline & & $\mathbf{N}$ & Max N & Min N & & $\mathbf{N}$ & Max N & Min N \\
\hline Andhra Pradesh & 2100 & 10540 & 1910 & 413 & 1355 & 5475 & 1004 & 297 \\
\hline Assam & 558 & 3185 & 1264 & 345 & 700 & 3395 & 1053 & 611 \\
\hline Bihar & 2155 & 12973 & 1319 & 576 & 1524 & 8178 & 869 & 271 \\
\hline Gujrat & 1422 & 8273 & 1569 & 603 & 853 & 4343 & 820 & 264 \\
\hline Haryana & 1722 & 11078 & 1649 & 383 & 1408 & 7536 & 1140 & 334 \\
\hline Himachal Pradesh & 1225 & 7179 & 1356 & 502 & 1163 & 5271 & 1050 & 475 \\
\hline Karnataka & 2523 & 15001 & 2572 & 244 & 2536 & 11985 & 1551 & 314 \\
\hline Kerala & 1474 & 8045 & 1408 & 822 & 703 & 2944 & 611 & 184 \\
\hline Madhya Pradesh & 4162 & 25083 & 1507 & 428 & 3158 & 15149 & 1098 & 219 \\
\hline Maharashtra & 2765 & 15323 & 1525 & 389 & 2160 & 10515 & 1120 & 356 \\
\hline Orissa & 1971 & 11354 & 2148 & 439 & 1506 & 7365 & 1406 & 391 \\
\hline Punjab & 1303 & 7983 & 1924 & 450 & 1160 & 5925 & 1816 & 386 \\
\hline Rajasthan & 1984 & 12558 & 1318 & 854 & 1712 & 9083 & 1082 & 240 \\
\hline Tamil Nadu & 1456 & 6990 & 1818 & 425 & 798 & 2940 & 657 & 207 \\
\hline Uttar Pradesh & 4036 & 25436 & 3143 & 321 & 2829 & 15927 & 1976 & 246 \\
\hline West Bengal & 1515 & 8927 & 1379 & 875 & 1290 & 5677 & 970 & 503 \\
\hline Rural India & 32371 & 189928 & 27809 & 8069 & 24855 & 121708 & 18223 & 5298 \\
\hline
\end{tabular}


Table 2: Total Rural Income Inequality, Regional Decomposition and Change over time

\begin{tabular}{|c|c|c|c|c|c|c|c|c|}
\hline & \multicolumn{3}{|c|}{1993} & \multicolumn{3}{|c|}{2011} & \multicolumn{2}{|c|}{$\begin{array}{l}\text { Change (2011- } \\
\text { 1993) }\end{array}$} \\
\hline & (1) & (2) & (3) & (4) & (5) & (6) & (7) & (8) \\
\hline & MLD & Theil & Gini & MLD & Theil & Gini & MLD & Theil \\
\hline $\begin{array}{l}\text { Total Inequality } \\
\text { (\% of Total) }\end{array}$ & $\begin{array}{l}0.356 \\
(100)\end{array}$ & $\begin{array}{l}0.394 \\
(100)\end{array}$ & 0.450 & $\begin{array}{l}0.474 \\
(100)\end{array}$ & $\begin{array}{l}0.549 \\
(100)\end{array}$ & 0.508 & $\begin{array}{l}0.118 \\
(100)\end{array}$ & $\begin{array}{l}0.155 \\
(100)\end{array}$ \\
\hline \multicolumn{9}{|c|}{ Decomposition (1) Total Inequality due to: } \\
\hline $\begin{array}{l}\text { Within-District } \\
\text { (\% of Total) }\end{array}$ & $\begin{array}{c}0.305 \\
(86)\end{array}$ & $\begin{array}{c}0.343 \\
(87)\end{array}$ & & $\begin{array}{c}0.384 \\
(81)\end{array}$ & $\begin{array}{c}0.451 \\
(82)\end{array}$ & & $\begin{array}{c}0.078 \\
(66)\end{array}$ & $\begin{array}{c}0.109 \\
(70)\end{array}$ \\
\hline $\begin{array}{l}\text { Between-District } \\
\text { (\% of Total) }\end{array}$ & $\begin{array}{c}0.051 \\
(14)\end{array}$ & $\begin{array}{c}0.051 \\
(13)\end{array}$ & & $\begin{array}{c}0.091 \\
(19)\end{array}$ & $\begin{array}{c}0.098 \\
(18)\end{array}$ & & $\begin{array}{c}0.040 \\
(34)\end{array}$ & $\begin{array}{c}0.047 \\
(30)\end{array}$ \\
\hline \multicolumn{9}{|c|}{ Decomposition (2) Between-District Inequality due to: } \\
\hline $\begin{array}{l}\text { Within-State } \\
\text { (\% of Total) }\end{array}$ & $\begin{array}{c}0.024 \\
(7)\end{array}$ & $\begin{array}{c}0.024 \\
(6)\end{array}$ & & $\begin{array}{c}0.032 \\
(7)\end{array}$ & $\begin{array}{c}0.034 \\
(6)\end{array}$ & & $\begin{array}{c}0.009 \\
(7)\end{array}$ & $\begin{array}{c}0.009 \\
(6)\end{array}$ \\
\hline $\begin{array}{l}\text { Between-State } \\
\text { (\% of Total) }\end{array}$ & $\begin{array}{c}0.027 \\
(8)\end{array}$ & $\begin{array}{c}0.027 \\
(7)\end{array}$ & & $\begin{array}{c}0.058 \\
(12)\end{array}$ & $\begin{array}{c}0.064 \\
(12)\end{array}$ & & $\begin{array}{c}0.031 \\
(26)\end{array}$ & $\begin{array}{c}0.037 \\
(24)\end{array}$ \\
\hline
\end{tabular}


Table 3a: Rural Income Inequality Decomposition by State: 1995

\begin{tabular}{|c|c|c|c|c|}
\hline State & Income Per Capita & MLD & Theil & Gini \\
\hline Andhra Pradesh & 17778 & 0.330 & 0.387 & 0.441 \\
\hline Assam & 17490 & 0.173 & 0.164 & 0.319 \\
\hline Bihar & 12164 & 0.283 & 0.317 & 0.398 \\
\hline Gujrat & 18526 & 0.465 & 0.555 & 0.512 \\
\hline Haryana & 21981 & 0.289 & 0.306 & 0.406 \\
\hline Himachal Pradesh & 13956 & 0.281 & 0.269 & 0.394 \\
\hline Karnataka & 16118 & 0.471 & 0.539 & 0.516 \\
\hline Kerala & 20534 & 0.317 & 0.381 & 0.428 \\
\hline Madhya Pradesh & 13817 & 0.297 & 0.336 & 0.421 \\
\hline Maharashtra & 19893 & 0.380 & 0.417 & 0.472 \\
\hline Orissa & 9387 & 0.324 & 0.320 & 0.428 \\
\hline Punjab & 23439 & 0.380 & 0.397 & 0.467 \\
\hline Rajasthan & 14078 & 0.315 & 0.344 & 0.427 \\
\hline Tamil Nadu & 17845 & 0.361 & 0.361 & 0.448 \\
\hline Uttar Pradesh & 13157 & 0.350 & 0.360 & 0.439 \\
\hline West Bengal & 10499 & 0.218 & 0.228 & 0.356 \\
\hline & \multicolumn{2}{|c|}{ State Level Inequality (MLD) } & \multicolumn{2}{|c|}{ State Level Inequality (Theil) } \\
\hline \multicolumn{4}{|l|}{ State } & Between-District \\
\hline Andhra Pradesh & $92 \%$ & $6 \%$ & $92 \%$ & $8 \%$ \\
\hline Assam & $99 \%$ & $1 \%$ & $99 \%$ & $2 \%$ \\
\hline Bihar & $97 \%$ & $2 \%$ & $97 \%$ & $3 \%$ \\
\hline Gujrat & $90 \%$ & $9 \%$ & $91 \%$ & $10 \%$ \\
\hline Haryana & $93 \%$ & $5 \%$ & $93 \%$ & $8 \%$ \\
\hline Himachal Pradesh & $94 \%$ & $4 \%$ & $94 \%$ & $7 \%$ \\
\hline Karnataka & $91 \%$ & $8 \%$ & $93 \%$ & $8 \%$ \\
\hline Kerala & $90 \%$ & $8 \%$ & $91 \%$ & $10 \%$ \\
\hline Madhya Pradesh & $87 \%$ & $9 \%$ & $88 \%$ & $13 \%$ \\
\hline Maharashtra & $95 \%$ & $4 \%$ & $95 \%$ & $5 \%$ \\
\hline Orissa & $96 \%$ & $3 \%$ & $96 \%$ & $4 \%$ \\
\hline Punjab & $97 \%$ & $2 \%$ & $97 \%$ & $3 \%$ \\
\hline Rajasthan & $86 \%$ & $10 \%$ & $88 \%$ & $14 \%$ \\
\hline Tamil Nadu & $93 \%$ & $6 \%$ & $93 \%$ & $8 \%$ \\
\hline Uttar Pradesh & $94 \%$ & $5 \%$ & $94 \%$ & $6 \%$ \\
\hline West Bengal & $96 \%$ & $3 \%$ & $96 \%$ & $4 \%$ \\
\hline
\end{tabular}


Table 3b: Rural Income Inequality Decomposition by State: 2011

\begin{tabular}{|c|c|c|c|c|}
\hline State & $\begin{array}{l}\text { Mean Income Per } \\
\text { Capita }\end{array}$ & MLD & Theil & Gini \\
\hline Andhra Pradesh & 18524 & 0.365 & 0.364 & 0.432 \\
\hline Assam & 20909 & 0.396 & 0.403 & 0.465 \\
\hline Bihar & 12194 & 0.419 & 0.472 & 0.472 \\
\hline Gujarat & 26795 & 0.635 & 0.633 & 0.575 \\
\hline Haryana & 29852 & 0.457 & 0.479 & 0.490 \\
\hline Himachal Pradesh & 33988 & 0.417 & 0.447 & 0.482 \\
\hline Karnataka & 19843 & 0.391 & 0.436 & 0.457 \\
\hline Kerala & 44989 & 0.403 & 0.480 & 0.462 \\
\hline Madhya Pradesh & 13495 & 0.476 & 0.614 & 0.514 \\
\hline Maharashtra & 21107 & 0.395 & 0.392 & 0.465 \\
\hline Orissa & 11709 & 0.302 & 0.329 & 0.418 \\
\hline Punjab & 36976 & 0.437 & 0.510 & 0.498 \\
\hline Rajasthan & 20039 & 0.365 & 0.388 & 0.451 \\
\hline Tamil Nadu & 26094 & 0.333 & 0.343 & 0.418 \\
\hline Uttar Pradesh & 13264 & 0.419 & 0.450 & 0.481 \\
\hline \multirow[t]{2}{*}{ West Bengal } & 16950 & 0.480 & 0.906 & 0.511 \\
\hline & \multicolumn{2}{|c|}{ State Level Inequality (MLD) } & \multicolumn{2}{|c|}{ State Level Inequality (Theil) } \\
\hline State & Within-District & Between-District & Within-District & Between-District \\
\hline Andhra Pradesh & $97 \%$ & $3 \%$ & $97 \%$ & $3 \%$ \\
\hline Assam & $95 \%$ & $4 \%$ & $95 \%$ & $6 \%$ \\
\hline Bihar & $96 \%$ & $4 \%$ & $96 \%$ & $4 \%$ \\
\hline Gujarat & $92 \%$ & $9 \%$ & $93 \%$ & $8 \%$ \\
\hline Haryana & $96 \%$ & $4 \%$ & $96 \%$ & $4 \%$ \\
\hline Himachal Pradesh & $97 \%$ & $2 \%$ & $98 \%$ & $3 \%$ \\
\hline Karnataka & $95 \%$ & $4 \%$ & $95 \%$ & $5 \%$ \\
\hline Kerala & $95 \%$ & $4 \%$ & $96 \%$ & $4 \%$ \\
\hline Madhya Pradesh & $89 \%$ & $10 \%$ & $91 \%$ & $10 \%$ \\
\hline Maharashtra & $88 \%$ & $10 \%$ & $88 \%$ & $13 \%$ \\
\hline Orissa & $97 \%$ & $2 \%$ & $97 \%$ & $3 \%$ \\
\hline Punjab & $96 \%$ & $3 \%$ & $97 \%$ & $3 \%$ \\
\hline Rajasthan & $87 \%$ & $10 \%$ & $88 \%$ & $14 \%$ \\
\hline Tamil Nadu & $95 \%$ & $4 \%$ & $95 \%$ & $5 \%$ \\
\hline Uttar Pradesh & $93 \%$ & $6 \%$ & $93 \%$ & $8 \%$ \\
\hline West Bengal & $84 \%$ & $15 \%$ & $90 \%$ & $12 \%$ \\
\hline
\end{tabular}


Table 4: Total Urban Income Inequality and its Decomposition: 2011

\begin{tabular}{|c|c|c|c|}
\hline & \multicolumn{2}{|c|}{2011} & \multirow[b]{2}{*}{ (3) } \\
\hline & (1) & (2) & \\
\hline & MLD & Theil & Gini \\
\hline Total Inequality & 0.430 & 0.466 & 0.490 \\
\hline (\% of Total) & $(100 \%)$ & $(100 \%)$ & \\
\hline \multicolumn{4}{|c|}{ Decomposition 1: Total Inequality Due to } \\
\hline Within-District & 0.350 & 0.385 & \\
\hline (\% of Total) & $(82 \%)$ & $(82 \%)$ & \\
\hline Between-District & 0.079 & 0.082 & \\
\hline (\% of Total) & $(18 \%)$ & $(18 \%)$ & \\
\hline \multicolumn{4}{|c|}{ Decomposition 2: Between-District Inequality Due to: } \\
\hline Within-State & 0.048 & 0.049 & \\
\hline (\% of Total) & $(11 \%)$ & $(11 \%)$ & \\
\hline Between-State & 0.031 & 0.033 & \\
\hline (\% of Total) & (7\%) & $(7 \%)$ & \\
\hline
\end{tabular}


Table 5: The contribution of each factor to income inequality in rural India in 1993 and 2011 and change in Inequality between 1993-2011

\begin{tabular}{lccccc}
\hline & \multicolumn{3}{c}{ Change between } & & \multicolumn{2}{c}{ Spatial control: state } \\
& \multicolumn{2}{c}{ Spatial control: district } & 2011 and 1991 & 1993 & 2011 \\
\cline { 2 - 6 } & 1993 & 2011 & & $(3)$ & $(5)$ \\
\cline { 2 - 6 } & & & & & \\
Gini & 0.450 & 0.508 & 0.058 & 0.450 & 0.508 \\
Share of different factors & & & & & \\
Residual & 57.69 & 68.15 & 149.29 & 63.98 & 72.93 \\
Scheduled Caste/Tribe & 1.38 & 0.53 & -6.02 & 1.48 & 0.56 \\
Muslim & 0.05 & 0.19 & 1.30 & -0.04 & 0.15 \\
Head Gender & 0.01 & 0.08 & 0.62 & 0.01 & 0.08 \\
Head Age & 0.64 & 1.42 & 7.44 & 0.62 & 1.40 \\
Education & 3.67 & 2.83 & -3.66 & 3.49 & 2.88 \\
Head's Occupation & 1.25 & 1.26 & 1.41 & 1.20 & 1.39 \\
HH main income source type & 3.75 & 2.34 & -8.58 & 3.94 & 2.42 \\
Household composition & 5.25 & 5.18 & 4.63 & 5.36 & 4.98 \\
Land Cultivated & 3.66 & -0.02 & -28.55 & 3.25 & 0.06 \\
Amount of Land Cultivated & 7.29 & 1.07 & -47.20 & 7.49 & 1.11 \\
Productive asset & 3.47 & 2.90 & -1.53 & 3.62 & 3.13 \\
Government scheme & 0.03 & 0.19 & 1.46 & 0.05 & 0.23 \\
District Fixed Effects & $\mathbf{1 1 . 8 7}$ & $\mathbf{1 3 . 8 7}$ & 29.38 & & \\
State Fixed Effects & & & & $\mathbf{5 . 5 5}$ & $\mathbf{8 . 6 8}$ \\
\hline
\end{tabular}




\section{Appendix}

Table A1: Total Consumption Rural Inequality, Regional Decomposition and Change over time: National Sample Survey (NSS)

\begin{tabular}{|c|c|c|c|c|c|c|c|c|}
\hline & \multicolumn{3}{|c|}{1999} & \multicolumn{3}{|c|}{2011} & \multicolumn{2}{|c|}{$\begin{array}{l}\text { Change (2011- } \\
\text { 1999) }\end{array}$} \\
\hline & (1) & (2) & (3) & (4) & (5) & (6) & (7) & (8) \\
\hline & MLD & Theil & Gini & MLD & Theil & Gini & MLD & Theil \\
\hline $\begin{array}{l}\text { Total Inequality } \\
\text { (\% of Total) }\end{array}$ & $\begin{array}{l}0.112 \\
(100)\end{array}$ & $\begin{array}{l}0.128 \\
(100)\end{array}$ & 0.263 & $\begin{array}{l}0.165 \\
(100)\end{array}$ & $\begin{array}{l}0.231 \\
(100)\end{array}$ & 0.312 & $\begin{array}{l}0.053 \\
(100)\end{array}$ & $\begin{array}{l}0.103 \\
(100)\end{array}$ \\
\hline \multicolumn{9}{|c|}{ Decomposition (1) Total Inequality due to: } \\
\hline $\begin{array}{l}\text { Within-District } \\
\text { (\% of Total) }\end{array}$ & $\begin{array}{c}0.083 \\
(74)\end{array}$ & $\begin{array}{c}0.099 \\
(77)\end{array}$ & & $\begin{array}{c}0.115 \\
(70)\end{array}$ & $\begin{array}{c}0.178 \\
(77)\end{array}$ & & $\begin{array}{c}0.032 \\
(60)\end{array}$ & $\begin{array}{c}0.079 \\
(77)\end{array}$ \\
\hline $\begin{array}{l}\text { Between-District } \\
\text { (\% of Total) }\end{array}$ & $\begin{array}{c}0.029 \\
(26)\end{array}$ & $\begin{array}{c}0.030 \\
(23)\end{array}$ & & $\begin{array}{c}0.049 \\
(30)\end{array}$ & $\begin{array}{c}0.054 \\
(23)\end{array}$ & & $\begin{array}{c}0.021 \\
(40)\end{array}$ & $\begin{array}{c}0.024 \\
(23)\end{array}$ \\
\hline \multicolumn{9}{|c|}{ Decomposition (2) Between-District Inequality due to: } \\
\hline $\begin{array}{l}\text { Within-State } \\
\text { (\% of Total) }\end{array}$ & $\begin{array}{c}0.013 \\
(11)\end{array}$ & $\begin{array}{c}0.013 \\
(10)\end{array}$ & & $\begin{array}{c}0.018 \\
(11)\end{array}$ & $\begin{array}{c}0.020 \\
(9)\end{array}$ & & $\begin{array}{c}0.005 \\
(10)\end{array}$ & $\begin{array}{c}0.007 \\
(7)\end{array}$ \\
\hline $\begin{array}{l}\text { Between-State } \\
\text { (\% of Total) }\end{array}$ & $\begin{array}{c}0.016 \\
(14)\end{array}$ & $\begin{array}{c}0.017 \\
(13)\end{array}$ & & $\begin{array}{c}0.031 \\
(19)\end{array}$ & $\begin{array}{c}0.034 \\
(15)\end{array}$ & & $\begin{array}{c}0.015 \\
(29)\end{array}$ & $\begin{array}{r}0.017 \\
(16)\end{array}$ \\
\hline
\end{tabular}


Table A2: Total Consumption Urban Inequality, Regional Decomposition and Change over time: National Sample Survey (NSS)

\begin{tabular}{|c|c|c|c|c|c|c|c|c|}
\hline & \multicolumn{3}{|c|}{1999} & \multicolumn{2}{|l|}{2011} & \multicolumn{3}{|c|}{$\begin{array}{l}\text { Change (2011- } \\
\text { 1999) }\end{array}$} \\
\hline & (1) & $(2)$ & (3) & (4) & (5) & (6) & (7) & (8) \\
\hline & MLD & Theil & Gini & MLD & Theil & Gini & MLD & Theil \\
\hline $\begin{array}{l}\text { Total Inequality } \\
\text { (\% of Total) }\end{array}$ & $\begin{array}{l}0.193 \\
(100)\end{array}$ & $\begin{array}{l}0.251 \\
(100)\end{array}$ & 0.346 & $\begin{array}{l}0.250 \\
(100)\end{array}$ & $\begin{array}{l}0.304 \\
(100)\end{array}$ & 0.390 & $\begin{array}{l}0.058 \\
(100)\end{array}$ & $\begin{array}{l}0.053 \\
(100)\end{array}$ \\
\hline \multicolumn{9}{|c|}{ Decomposition 1: Total Inequality Due to- } \\
\hline $\begin{array}{l}\text { Within-District } \\
\text { (\% of Total) }\end{array}$ & $\begin{array}{r}0.154 \\
(80)\end{array}$ & $\begin{array}{r}0.214 \\
(85)\end{array}$ & & $\begin{array}{r}0.189 \\
(75)\end{array}$ & $\begin{array}{r}0.243 \\
(80)\end{array}$ & & $\begin{array}{r}0.034 \\
(59)\end{array}$ & $\begin{array}{r}0.029 \\
(55)\end{array}$ \\
\hline Between-District & 0.038 & 0.038 & & 0.062 & 0.061 & & 0.023 & 0.024 \\
\hline (\% of Total) & (20) & (15) & & $(25)$ & $(20)$ & & $(41)$ & $(45)$ \\
\hline \multicolumn{9}{|c|}{ Decomposition 2: Between-District Inequality Due to- } \\
\hline Within-State & 0.026 & 0.026 & & 0.047 & 0.047 & & 0.020 & 0.021 \\
\hline (\% of Total) & $(14)$ & (10) & & (19) & (15) & & (35) & (39) \\
\hline Between-State & 0.012 & 0.011 & & 0.015 & 0.015 & & 0.003 & 0.003 \\
\hline (\% of Total) & (6) & (5) & & (6) & (5) & & (5) & (6) \\
\hline
\end{tabular}




\begin{tabular}{|c|c|c|}
\hline & 1993 & 2011 \\
\hline \multicolumn{3}{|c|}{ Dependent variable: log of real per capita income } \\
\hline \multirow[t]{2}{*}{ Scheduled Caste/Tribe } & $-0.117^{* * *}$ & $-0.122 * * *$ \\
\hline & $(0.008)$ & $(0.013)$ \\
\hline \multirow[t]{2}{*}{ Muslim } & $-0.023 *$ & $-0.120 * * *$ \\
\hline & $(0.014)$ & $(0.019)$ \\
\hline \multirow[t]{2}{*}{ Head's is female } & $0.084 * * *$ & $0.143 * * *$ \\
\hline & $(0.017)$ & $(0.019)$ \\
\hline \multirow[t]{2}{*}{ Head age } & $-0.003 *$ & $0.008 * * *$ \\
\hline & $(0.002)$ & $(0.003)$ \\
\hline \multirow[t]{2}{*}{ Head age-square } & $0.000 * * *$ & 0.000 \\
\hline & $(0.000)$ & $(0.000)$ \\
\hline \multicolumn{3}{|l|}{ Head's Education } \\
\hline \multirow[t]{2}{*}{ Primary } & $0.118 * * *$ & $0.065 * * *$ \\
\hline & $(0.011)$ & $(0.015)$ \\
\hline \multirow[t]{2}{*}{ Middle } & $0.169 * * *$ & $0.149 * * *$ \\
\hline & $(0.012)$ & $(0.017)$ \\
\hline \multirow[t]{2}{*}{ Secondary } & $0.296 * * *$ & $0.292^{* * *}$ \\
\hline & $(0.015)$ & $(0.020)$ \\
\hline \multirow[t]{2}{*}{ Higher Secondary } & $0.350 * * *$ & $0.276 * * *$ \\
\hline & $(0.024)$ & $(0.027)$ \\
\hline \multirow[t]{2}{*}{ Tertiary } & $0.548 * * *$ & $0.540 * * *$ \\
\hline & $(0.024)$ & $(0.032)$ \\
\hline \multicolumn{3}{|l|}{ Head's occupation } \\
\hline \multirow[t]{2}{*}{ Farmer } & 0.012 & $-0.080 * * *$ \\
\hline & $(0.012)$ & $(0.020)$ \\
\hline \multirow[t]{2}{*}{ Salaried job } & $0.238 * * *$ & $0.213^{* * *}$ \\
\hline & $(0.018)$ & $(0.032)$ \\
\hline \multirow[t]{2}{*}{ Non-agriculture labor } & $0.079 * * *$ & $0.099 * * *$ \\
\hline & $(0.018)$ & $(0.022)$ \\
\hline \multirow[t]{2}{*}{ Whether cultivate any land } & $0.275^{* * *}$ & 0.007 \\
\hline & $(0.012)$ & $(0.015)$ \\
\hline \multirow[t]{2}{*}{ Amount of land cultivated per person } & $0.017^{* * *}$ & $0.065^{* * *}$ \\
\hline & $(0.000)$ & $(0.004)$ \\
\hline \multirow[t]{2}{*}{ Dependency Ratio } & $-0.178 * * *$ & $-0.105^{* * *}$ \\
\hline & $(0.010)$ & $(0.013)$ \\
\hline \multirow[t]{2}{*}{ Household Size } & $-0.046 * * *$ & $-0.063 * * *$ \\
\hline & $(0.004)$ & $(0.005)$ \\
\hline \multirow[t]{2}{*}{ Number of adult male } & 0.012 & $0.066 * * *$ \\
\hline & $(0.007)$ & $(0.010)$ \\
\hline \multirow[t]{2}{*}{ Number of adult female } & $-0.045^{* * *}$ & $0.022 * *$ \\
\hline & $(0.008)$ & $(0.011)$ \\
\hline
\end{tabular}


Household main income source

Cultivation

$\begin{array}{cc}0.086 * * * & -0.162 * * * \\ (0.012) & (0.021) \\ -0.044 * * * & -0.054^{* *} \\ (0.016) & (0.021) \\ 0.351 * * * & 0.245^{* * *} \\ (0.017) & (0.028)\end{array}$

Household have any productive asset

Tractor

$\begin{array}{cc}0.324 * * * & 0.621 * * * \\ (0.021) & (0.030)\end{array}$

Tube well

$0.236 * * * \quad 0.222 * * *$

Animal

(0.014) (0.019)

$0.043^{* * *} \quad-0.023 *$

Household benefited from any government

(0.009) (0.013)

scheme

$0.012-0.072^{* * *}$

(0.010) (0.014)

Constant

$9.257 * * * \quad 9.172 * * *$

(0.039) (0.069)

Observations

31,955

23,100

R-squared

0.446

0.319 